\title{
National human embryo and embryoid research policies: a survey of 22 top research-intensive countries
}

\author{
Kirstin RW Matthews*,1(D) \& Daniel Moralí ${ }^{1}$ \\ ${ }^{1}$ Baker Institute Center for Health \& Biosciences; Rice University; Houston, TX 77005, USA \\ *Author for correspondence: krwm@rice.edu
}

\begin{abstract}
Research using human embryos and embryoids has expanded in recent years due to technological advances. Surveying laws and guidelines among the top research and development (R\&D) investing nations highlights existing barriers to expanding this area of research. Of the 22 nations surveyed, we found 12 countries with a 14-day limit, one with a seven-day limit, five with prohibitions and four without national laws or guidelines that limit or prohibit human embryo research. Sixteen national laws or guidelines define an embryo or related entities, with five nations limiting human embryoid research. Other laws are ambiguous in relation to embryoid research, leave unanswered questions regarding what research is permitted or restricted and need additional clarity for researchers.
\end{abstract}

First draft submitted: 28 October 2019; Accepted for publication: 29 July 2020; Published online: 17 August 2020

Keywords: embryoids • embryos $\bullet$ human embryonic stem cells $\bullet$ human embryo research $\bullet$ law $\bullet$ pluripotent stem cells $\bullet$ policy $\bullet$ public policy $\bullet$ science policy $\bullet$ synthetic embryos

Technological developments in human embryo research have led scientists and other scholars to question existing human embryo research guidelines, especially the 14-day limit [1-9]. The 14-day limit is a boundary that prohibits scientists from culturing or conducting research on an in vitro human embryo beyond 14 days after fertilization or after the development of the primitive streak. It originated from recommendations from two reports on in vitro fertilization (IVF), one from the USA and one from the UK: the 1979 US Department of Health, Education, and Welfare (DHEW) report and the 1984 UK Warnock report [10-12]. Both reports recommended restricting human embryo research to 14 days of development and, in the UK, the recommendation was implemented in the Human Fertilisation and Embryology Act of 1990 [10-13]. The limit of 14 days was justified for several reasons: the primitive streak appears around 14 days; the primitive streak can be easily identified in culture and is the first visible sign of organization of the embryo just prior to neural tube formation; it is the last point at which twinning can occur (some scholars suggest that this is a point of individuation); and when the rule was established, it was technologically infeasible to culture human embryos beyond 14 days; thus, it imposed no limits on research [6,8-13].

The 14-day limit is found in several international scientific and medical society guidelines. For example, the 2016 stem cell research guidelines from the International Society for Stem Cell Research (ISSCR), which represents more than 4000 scientists worldwide, included a 14-day limit on human embryo research [14-16]. ISSCR justified this recommendation at the time as a "broad international consensus that such experiments [involving culture beyond 14 days] lack a compelling scientific rationale, raise substantial ethical concerns, and/or are illegal in many jurisdictions" [14]. In addition, the US National Academies of Sciences, Engineering and Medicine (NASEM) included the 14-day limit within its guidelines for human embryonic stem cell (hESC) research [17].

Two distinct research developments have encouraged scholars to revisit human embryo research polices and the 14-day limit. First, two independent research groups, one in the USA and one in the UK, were able to culture human embryos in vitro up to the 14-day stage to understand early human development, including how embryo cells organize, differentiate, and generate extraembryonic tissues to allow proper implantation. However, they did not expand their experiments to later developmental points due to the 14-day limit, to respect an international norm and, in the case of the UK team, to stay in compliance with the law $[18,19]$. 
The second research advancement involved developing lab models of early human embryos using pluripotent stem cells (PSCs), specifically hESCs or induced pluripotent stem cells (iPSCs) [20-29]. These models are known by various names, including references to developmental time points (i.e., blastoids and gastruloids) or to cells used to create the model (i.e., micropatterned hESC colonies or post-implantation amniotic sac embryoid, PASE) [20-22,29]. A few groups have also suggested general names to be used for the field, such as artificial embryos, embryoids, or synthetic entities with embryo-like features (SHEEF) $[23,29,30]$. For this article, we chose to use the term embryoid as a general term to include all PSC-derived models of early embryo development, whether they represent all or part of the developing embryo (but are not in fact a human embryo derived via fertilization). Although not perfect, the term is already in use, reflects what these entities are trying to model (embryos), is consistent with original descriptions of embryoid bodies from mouse ESC work, and links to broader research on organoids that are also PSC-cultured incomplete models of tissue architecture and function [23,29,31-35].

As described above, embryoids mimic aspects of early embryo developmental stages, such as a blastocyst (day 5) or gastrula (day 17) stage [23-32,36]. However, they are not embryos and are unable to become a fully functional human embryo (due to absent cells or tissues vital for implantation). In contrast to embryos created via fertilization, embryoids are created in a lab from existing PSC culture lines and therefore permit the study of early development without having to create (via fertilization) or destroy human embryos [23-32,36]. Furthermore, embryoids developed from iPSCs do not involve any embryos, therefore avoiding some of the ethical concerns associated with hESCs and embryo research. Embryoids now make possible the study and genetic manipulation of larger numbers of samples than normally would be available due to limited IVF sources and are viewed as an alternative to using human embryos. They allow scientists to test theories and hypotheses prior to working on human embryos, ultimately improving our knowledge of early human development $[1,23,24]$.

What human embryo and embryoid research is permitted or prohibited varies from country to country. Each nation develops their own policies to serve their internal interests and goals as well as based on national culture, history, politics and religion [37]. Many nations view science and technology as a mechanism for improving their economy as well as social well-being [38]. Those who invest heavily in R\&D are major producers of scientific outputs, in terms of science and engineering academic publications and patents [39,40]. To understand the variations and impact of national policies, we reviewed and analyzed IVF, hESC and human embryo research laws or national guidelines currently in place in the top research and development $(R \& D)$ investing nations, whether they had restriction on human embryo research, including a 14-day limit, and if the policies impacted embryoids research.

For this article, we focused on the top 22 countries based on funding - spending US $\$ 15$ billion or more for $R \& D$ in 2017 (Table 1). Investment in R\&D is traditionally captured in two forms: gross expenditures in R\&D (GERD), which describes total investment (public and private) in $\mathrm{R} \& \mathrm{D}$, and national research intensity, which measures a country's GERD as a percentage of its gross domestic product (GDP). Research intensity provides an indicator for how a country prioritizes R\&D within their budget [38]. Representing more than $90 \%$ of global R\&D investment, these 22 countries geographically span Asia, Europe, North America, South America, the Middle East and Oceania [38]. More than $80 \%$ of the 2.6 million science and engineering articles were authored by scientists from one of these countries [39]. Due to their strong investment in R\&D, we believe they are the ideal selection of countries to study as their national laws or guidelines influence the global standards of practice for R\&D.

For each of the 22 counties, we identified national laws and guidelines (set by governmental departments, agencies or ministries) that explicitly included one or more of the following terms: 'human embryo,' 'cloning,' 'in vitro fertilization,' and 'embryonic stem cells.' The statutory interpretations were limited to the plain language of said documents and excluded legislative history and case law.

The review of laws and guidelines centered on two areas: to determine if there is a 14-day limit or other restriction on human embryo research; and to ascertain if the definitions of a human embryo permit or prohibit human embryoid research. The focus was on the in vitro culture of human embryo or embryoids for basic research. While other restrictions to basic research on human embryos might exist, such as limits to heritable germline modifications or applied research on IVF eggs (with the goal of developing a pregnancy), these laws and guidelines are outside of the scope of the paper.

From our review of 22 nations, we identified 12 countries with a 14-day limit in their laws or governmental guidelines. Of the remaining ten countries, five prohibit human embryo research, one has a 7-day limit, and four have no date limit in their national laws or guidelines. Sixteen nations' laws or guidelines define a human embryo or other related entity. In five countries, these definitions or laws prohibit embryoid research. However, most definitions are ambiguous, especially as it relates to embryoid research. This leaves unanswered questions regarding 
Table 1. Top 22 investors in science and technology R\&D and their human embryo laws/guidelines.

\begin{tabular}{|c|c|c|c|c|c|c|}
\hline Countries & GERD ${ }^{\dagger}$ (US $\$$ in billions) & GERD/GDP ${ }^{\dagger}$ & Policy & Embryo type & Developmental limit & Ref. \\
\hline USA & 549.0 & $2.81 \%$ & $\mathrm{~L}, \mathrm{G}^{\ddagger}$ & $\mathrm{S}, \mathrm{R}, \mathrm{SCNT}^{\ddagger}$ & 14-day§ & [50] \\
\hline China & 496.0 & $2.15 \%$ & $\mathrm{~L}$ & S, SCNT & 14-day & [78] \\
\hline Japan & 170.9 & $3.20 \%$ & L & S, SCNT & 14-day & {$[76,77]$} \\
\hline Germany & 132.0 & $3.04 \%$ & L & None & Prohibition & [53-55] \\
\hline South Korea & 91.0 & $4.55 \%$ & L & S, SCNT & 14-day & [83] \\
\hline France & 64.7 & $2.19 \%$ & $\mathrm{~L}, \mathrm{G}$ & $\mathrm{s}$ & NA & [47] \\
\hline India & 49.7 & $0.62 \%$ & $\mathrm{~L}$ & $S, R, S C N T$ & 14-day & [79] \\
\hline United Kingdom & 49.3 & $1.66 \%$ & L & $S, R, S C N T$ & 14-day & [61] \\
\hline Russia & 41.9 & $1.11 \%$ & L & None & Prohibition & [59] \\
\hline Brazil & 39.9 & $1.27 \%$ & G & $\mathrm{s}$ & NA & [41] \\
\hline Taiwan $\mathbb{I}$ & 39.3 & $3.30 \%$ & L & S, SCNT & 14-day & [71-73] \\
\hline Italy & 33.5 & $1.35 \%$ & L & None & Prohibition & [58] \\
\hline Canada & 27.2 & $1.59 \%$ & L & $\mathrm{s}$ & 14-day & {$[69,70]$} \\
\hline Spain & 21.9 & $1.21 \%$ & L & S, SCNT & 14-day & {$[81,82]$} \\
\hline Turkey & 21.7 & $0.96 \%$ & $\mathrm{~L}$ & None & Prohibition & [56] \\
\hline Australia & 21.2 & $1.88 \%$ & L & $S$ & 14-day & {$[66-68]$} \\
\hline Switzerland & 18.9 & $3.37 \%$ & L & $s$ & 7-day & [60] \\
\hline Netherlands & 18.6 & $1.99 \%$ & $\mathrm{~L}$ & S, SCNT & 14-day & [80] \\
\hline Sweden & 17.6 & $3.40 \%$ & L & $\mathrm{S}, \mathrm{R}, \mathrm{SCNT}$ & 14-day & [62] \\
\hline Israel & 15.4 & $4.54 \%$ & $\mathrm{~L}, \mathrm{G}^{\#}$ & $\mathrm{~S}, \mathrm{R}, \mathrm{SCNT}$ & 14-day" & [44-46] \\
\hline Belgium & 15.2 & $2.70 \%$ & L & $S, R, S C N T$ & 14-day & [63] \\
\hline Austria & 15.0 & $3.16 \%$ & L & None & Prohibition & [52] \\
\hline
\end{tabular}

$\dagger$ GERD and GDP data are from 2017 [except for Australia (2015), Brazil (2016), and India (2015)] and was obtained from US National Science Board 2020 Science and Engineering Indicators [38].

¥The US federal restriction (the Dickey-Wicker Amendment) only prohibits federally funded research that creates or destroys a human embryo.

§The US 14-day limit is not a federal policy or guideline, but was developed by a nongovernmental organization, the National Academies of Sciences, Engineering and Medicine.

I Taiwan was viewed separately from China as a 'country' because its GERD is reported separately from China, although it is traditionally referred to as an 'economy' because of its relationship with/to China.

\#Israel has a law banning reproductive cloning, but does not address other human embryo research. The guidelines address sources of embryos and the 14 -day rule. Top investors spent between $\$ 15.0$ billion (Austria) and US $\$ 549$ billion (US) on R\&D, with GERD/GDP ranging from $0.62 \%$ (India) to $4.55 \%$ (South Korea) [38]. For each country, policies were categorized by type (law, governmental guideline or funding limit), type of embryo allowed for research (supernumerary IVF, created for research, SCNT or none) and by their limit (the presence of a 14-day limit, 7-day limit, prohibition of human embryo research or none specified).

G: Nongovernmental guideline; GDP: Gross domestic product; GERD: Gross expenditures in research and development; L: National law or governmental guideline; NA: No applicable guideline or law; None: No embryo research permitted; R\&D: Research and development; S: Supernumerary IVF embryo; SCNT: Somatic cell nuclear transfer embryo.

what embryoid research is permitted or restricted. More clarity within these policies is needed in several countries, including the USA, if research is to continue.

\section{Human embryo research: national laws \& guidelines}

As it has been discussed previously, human embryo research laws and national guidelines are developed to serve each nation's internal interests and goals. These interests are often linked to a country's particular culture, history, politics, and religion [37]. For example, some countries, such as the UK and China, promote R\&D as a means for economic development. Others, including the US and Austria, find that research on human embryos challenges strongly held religious beliefs, and in the case of the USA, this makes passing any national legislation politically untenable [13,37]. Still other laws were influenced by the country's history. Such was the case of Germany's laws on hESC and embryo research, which were impacted by the nation's desire to be a champion of ethics as a result of unethical work conducted during World War II [37]. As a result, national human embryo research laws and guidelines are diverse in top R\&D investing countries. In regard to the presence of a 14-day limit, nations can be categorized into four groups: no limit, a prohibition, an alternative limit or the presence of the 14-day limit (Table 1).

Four countries did not have a date limit: Brazil, France, Israel and the USA. Brazil's laws on hESC research prohibit "genetic engineering on human germ cells, human zygotes or human embryos" but do not address a development limit or other restrictions on human embryo research [41-43]. Israel has a 1999 law banning reproductive cloning 
and a set of guidelines for hESC research, but it does not address nor limit in vitro human embryo research [44-46]. French law permits the use of leftover IVF embryos for scientific research if scientifically justified and with prior authorization by the Agency of Biomedicine [47,48]. This bioethics law is under review in 2020, and the new version could include more permissive language related to human embryo research, including potentially adding a 21 -day limit [49].

While the USA was the first to propose the 14-day limit, the limit was never passed as a federal law [10,11]. The USA does prohibit federal funding for human embryo research through the Dickey-Wicker Amendment $[10,13,50]$. This amendment has been passed annually within the federal budget for the US Department of Health and Human Services since 1995, prohibiting scientists from obtaining funding for human embryo research work from the US $\mathrm{NIH}$, which is one of the largest funders for biomedical research with an annual budget of approximately US $\$ 40$ billion. The Dickey-Wicker Amendment, named after the two legislators who developed it (Jay Dickey and Roger Wicker), specifically bans federal funding for "the creation of a human embryo or embryos for research purposes or research in which a human embryo or embryos are destroyed, discarded, or knowingly subject to risk of injury or death," including developing hESC lines [13,50]. The amendment only applies to federal funding and does not affect R\&D funded by state or local governments or private institutions [13]. In addition to federal laws, several US states have enacted laws limiting or restricting human embryo research, including South Dakota and Louisiana, which outright prohibit all human embryo research (state or private) [51].

Basic research on human embryos is prohibited in five countries: Austria, Germany, Italy, Russia and Turkey. These countries have prohibitions regarding the use of embryos for nonreproductive or medical purposes. Austria's Reproductive Medicine Act prohibits using cells capable of development for purposes other than medically assisted procreation [52]. Germany's Embryo Protection Act banned the creation of supernumerary embryos (embryos created for IVF but stored and not used) and embryos created for nonreproductive purposes (e.g., for research), eliminating all potential embryo sources for research [53-55]. Turkey's law for assisted reproduction technology (Regulation on Assisted Reproductive Treatment Practices and Assisted Reproductive Treatment Centers) prohibits the creation and storage of embryos for nonreproductive purposes [56,57]. In Italy, the Rules on Medically Assisted Procreation passed in 2004 state that 'any experimentation on a human embryo is prohibited' [58]. The only research allowed is for 'therapeutic and diagnostic purposes' and to protect 'the health and development of the embryo' [58]. Russian law, Federal Law on Biomedical Cell Products, prohibits the use of human embryos or their products for research as they cannot be used for 'biomedical cell products' [59].

Switzerland alone has an alternative time point, a 7-day limit (Federal Act on research Involving Embryonic Stem Cells) [60]. In Switzerland it is prohibited to "create an embryo for research purposes", "to modify the genetic material in a germ cell", "to create a clone, chimera, or hybrid", and "to use surplus embryos for any purpose other than the derivation of embryonic stem cells" [60]. This restriction allows for IVF research prior to day 7 as well as the derivations of hESCs (that occur around 5-6 days), but prohibits other in vitro human embryo research beyond day 7.

Twelve countries limit human embryo research to 14 days or the formation of the primitive streak: Australia, Belgium, Canada, China, India, Japan, the Netherlands, Spain, South Korea, Sweden, Taiwan and the UK. Arguably, the most well-known law is the UK Human Fertilisation and Embryology Act of 1990 [13,61]. It permits human embryo research prior to 14 days if deemed 'necessary and desirable,' while prohibiting 'keeping or using an embryo after the appearance of the primitive streak.' The Act allows the creation of embryos for research purposes, including through somatic cell nuclear transfer (SCNT), and established the Human Fertilisation and Embryology Authority (HFEA), an agency to oversee research [13,61].

Sweden's law, Genetics Integrity Act, and Belgium's law, In vitro Embryo Research Act, are similar to the UK's Human Fertilisation and Embryology Act and allow for the creation of embryos for research purposes [62,63]. Sweden permits "experiments for the purpose of research or treatment on fertilized eggs and eggs used for somatic cell nuclear transfer may be carried out no longer than up to and including the 14th day after fertilization or cell nuclear transfer respectively" [62]. Belgium allows human embryo research to advance medical knowledge, based on latest scientific findings, and with no other alternative available [63].

Other countries have slightly more restrictive policies. Australia, Canada, Japan, the Netherlands, Spain, South Korea and Taiwan allow human embryo research, but only on embryos created for IVF and donated for research [64,65]. Australia (Human Embryos Act), Canada (Tri-Council Policy Statement: Ethical Conduct for Research Involving Humans) and Taiwan (Human Embryo and Embryonic Stem Cell Act) have a 14-day limit within their laws and national guidelines [66-75]. Japan's Act on Regulation of Human Cloning Techniques does not include a 14-day limit, but the national guidelines from the Ministry of Education, Culture, Sports, Science and 
Technology do [76,77]. India and China do not have a law, but instead a 14-day limit is specified within their national hESC guidelines [64,78,79]. In Japan, the Netherlands, and Spain, the law on human embryo research contains a requirement for approval from a governmental body [64,76,77,80-82]. For example, the Netherlands' Embryo Act of 2002 permits research if "a positive opinion has been obtained from the central committee on the research protocol" [80]. In addition, Spain's Biomedical Research Law prohibits creating human pre-embryos and embryos for research purposes, but it does permit SCNT. Spain's law has the only mention of a pre-embryo in the laws reviewed and refers to the stage of embryo development prior to 14 days [81,82].

South Korea does not have a 14-day limit per se; instead, their law, the Bioethics and Safety Act, restricts research on human embryos to the time prior to the formation of the primitive streak $[64,83]$. This could potentially allow researchers to conduct work on human embryos slightly longer than 14 days, since developmental timing is not always consistent [84].

\section{Embryoid research}

National laws and guidelines that affect human embryo research and, more broadly, hESC research could also affect human embryoid research depending on their exact language. However, since this is a relatively new area, most national laws and guidelines do not explicitly state whether this research is permitted or restricted. Furthermore, many have also not publicly commented on the issue. One way to determine permissibility is to review how national laws and/or guidelines define an embryo. Of the 22 countries surveyed, only thirteen include definitions of an embryo in their laws or guidelines: Australia, Belgium, Canada, Germany, India, Japan, the Netherlands, South Korea, Spain, Switzerland, Taiwan, UK and the USA (Table 2).

Within the definition of an embryo, the UK Human Fertilisation and Embryology Act includes oversight of the creation of embryos "where fertilisation or any other process by which the embryo was created began outside of the human body whether or not it was completed. .." [61]. This language seems to imply that HFEA could oversee embryoid research if the regulators found them to be an embryo, although HFEA does not require licenses to create embryoids nor regulates them at this time [61].

In the USA, there is no federal law on human embryo research, just the restriction on federal funding through the Dickey-Wicker Amendment mentioned earlier $[13,50,85]$. How it impacts human embryoid research is unclear at present. The amendment explicitly defines a human embryo to include anything "derived by fertilization, parthenogenesis, cloning, or any other means from one or more human gametes or human diploid cell" [13,50]. Interpretations of this definition could affect funding for embryoid research at the NIH. As of 2020, there has been no public rulings or explicit guidelines on what is and is not fundable, nor has there been an official policy to guide scientists applying for or conducting NIH-funded research. Although it does not affect nonfederal research, the ambiguity leaves a level of uncertainty that scientists are having problems navigating $[1,85]$.

Of the remaining countries with embryo definitions, seven (Canada, India, the Netherlands, South Korea, Spain, Switzerland and Taiwan) allow human embryoid research and four have prohibitive language (Australia, Belgium, Germany and Japan). In Belgium, Japan, and the Netherlands, the definition of an embryo includes cells with the potential to develop into a human being, which would include embryoids $[63,66,67,80]$. The Dutch law is permissive, allowing the creation and use of hESCs in research, which are the main source of embryoids [80]. In contrast, the Belgian and Japanese laws restrict research. Their laws limit all research using hESCs to 14 days or before, including embryoids created from hESC, such as gastruloids (which mimic day 17) [63,66,67]. While some scientists argue that current embryoid models do not in fact have a potential to become a human being, it is unclear whether policymakers in these countries will take similar views and permit some or all embryoid research $[85,86]$.

Australian and German laws define embryos in a manner which restricts human embryoid research. Australia's law prohibits any 'process that initiates organised development of a biological entity' [66-68]. This definition of an embryo was developed to prohibit reproductive cloning, but also restricts embryoid research, despite the country's otherwise permissive hESC policy [84]. Germany's prohibition of human embryo research defines an embryo as any "totipotent cell taken from an embryo, which is able to divide and become an individual." This language could restrict research on more advanced embryoids created from hESCs that have the capability to be cultured into later stages of human development. However, some embryoids developed from iPSCs, which are not derived from an embryo, could be permitted.

Several nations have laws or guidelines allowing embryoid research. Canada's definition of an embryo explicitly prohibits reproductive cloning alone and allows for hESC research and, therefore, embryoid research [69,70,74,75]. India, Spain, South Korea and Taiwan mention fertilization as part of their definition. Since embryoid research 
Table 2. Definitions and restrictions to human embryoid research.

\begin{tabular}{|c|c|c|c|}
\hline Country & Definition & $\begin{array}{l}\text { Embryoid } \\
\text { restriction }\end{array}$ & Ref. \\
\hline Australia & $\begin{array}{l}\text { Human embryo means a discrete entity that has arisen from either: (a) the first mitotic division when } \\
\text { fertilisation of a human oocyte by a human sperm is complete; or (b) any other process that initiates } \\
\text { organised development of a biological entity with a human nuclear genome or altered human nuclear } \\
\text { genome that has the potential to develop up to, or beyond, the stage at which the primitive streak } \\
\text { appears; and has not yet reached } 8 \text { weeks of development science the first mitotic division }\end{array}$ & Yes & [66-68] \\
\hline Austria & $\begin{array}{l}\text { Fertilized oocytes and cells derived from them shall be considered viable cells. Developmentally capable } \\
\text { cells may not be used for purposes other than medically assisted reproductive }{ }^{\dagger}\end{array}$ & Yes & [52] \\
\hline Belgium & Embryo: the cell or the organic set of cells capable, as they develop, of becoming a human being ${ }^{\dagger}$ & Yes & [63] \\
\hline Brazil & NA & No & [41-43] \\
\hline Canada & $\begin{array}{l}\text { Embryo means an a human organism during the first } 56 \text { days of its development following fertilization or } \\
\text { creation, excluding any time during which its development has been suspended, and includes any cell } \\
\text { derived from such an organism that is used for the purpose of creating a human being. (Assisted Human } \\
\text { Reproduction Act) }\end{array}$ & No & {$[69,70,74,75]$} \\
\hline China & NA & No & {$[65,78]$} \\
\hline France & NA & No & {$[47,48]$} \\
\hline Germany & $\begin{array}{l}\text { Embryo is any totipotent cell which, if the necessary conditions are met, is able to divide and develop into } \\
\text { an individual. ( } 2002 \mathrm{Act}) \text { For the purpose of this act, the embryo is the fertilized, developable human } \\
\text { oocyte from the time of nuclear fusion, and any totipotent cell taken from an embryo, which, if the } \\
\text { necessary conditions are met, can be divided and become an individual. }{ }^{\dagger}(1990 \mathrm{Act})\end{array}$ & Yes & [53-55] \\
\hline India & $\begin{array}{l}\text { Human embryo: It is the development stage from [the] time of fertilization until the end of the eight week } \\
\text { of gestation, after which it is known as a fetus. The term 'early embryo' covers stages of development up to } \\
\text { the appearance of [the] primitive streak i.e., until } 14 \text { days after fertilization }\end{array}$ & No & [79] \\
\hline Israel & NA & No & [44-46] \\
\hline Italy & NA & No & [58] \\
\hline Japan & $\begin{array}{l}\text { Embryo- a cell (except for a Germ Cell) or a cell group which has the potential to grow into an individual } \\
\text { through the process of development in utero of a human or an animal and remains at a stage prior to } \\
\text { placental formation }{ }^{\dagger}\end{array}$ & Yes & {$[65,76,77]$} \\
\hline Netherlands & Embryo: cell or set of cells with the capacity to grow into a human ${ }^{\dagger}$ & No & [80] \\
\hline Russia & $\begin{array}{l}\text { The Law establishes...the inadmissibility of creating a human embryo for the production of biomedical cell } \\
\text { products; the inadmissibility of using biological material obtained by suspension or interruption of the } \\
\text { development of a human embryo or fetus for the development, production and use of biomedical cell } \\
\text { products }\end{array}$ & Yes & [59] \\
\hline South Korea & $\begin{array}{l}\text { EMBRYO: a fertilized oocyte (or segmented cells) from the moment of fertilization to the point of time at } \\
\text { which all organs of the given organism have developed embryologically }\end{array}$ & No & {$[65,83]$} \\
\hline Spain & $\begin{array}{l}\text { Embryo is the stage of embryonic development from the moment the fertilized oocyte is implanted in the } \\
\text { uterus until the onset of organogenesis, which ends at } 56 \text { days post fertilization. Pre-embryo is an in vitro } \\
\text { embryo from the fertilization of the oocyte through } 14 \text { days post fertilization }{ }^{\dagger}\end{array}$ & No & {$[81,82]$} \\
\hline Sweden & No 'embryo' definitions in the law, instead uses the term 'fertilized egg' $\dagger$ & No & [62] \\
\hline Switzerland & $\begin{array}{l}\text { Embryo means the offspring, from the fusion of the cell nuclei (karyogamy) to the completion of organ } \\
\text { development }\end{array}$ & No & [60] \\
\hline Taiwan $\ddagger$ & $\begin{array}{l}\text { EMBRYO: Human embryos for research (hereafter referred to as embryos for research): refer to the } \\
\text { embryonic tissue that have been available for research in accordance with these regulations and have not } \\
\text { been divided for more than } 14 \text { days and the primitive streak has not appeared (Human Embryo and } \\
\text { Embryonic Stem Cell Act). Embryo: refers to a fertilized oocyte that has undergone division for less than } \\
\text { eight weeks (Assisted Reproduction Act) }\end{array}$ & No & {$[65,71-73]$} \\
\hline Turkey & NA & No & {$[56,57]$} \\
\hline United Kingdom & $\begin{array}{l}\text { Embryo means a live human embryo and does not include human admixed embryo (as defined by section } \\
\text { 4A[6]), and references to the embryo include an egg that is in the process of fertilization or is undergoing } \\
\text { any other process capable of resulting in an embryo }\end{array}$ & No & {$[13,61]$} \\
\hline United States & $\begin{array}{l}\text { The term 'human embryo or embryos' includes any organism, not protected as a human subject under } 45 \\
\text { CFR } 46 \text { as of the date of the enactment of this Act, that is derived by fertilization, parthenogenesis, cloning } \\
\text { or any other means from one or more human gametes or human diploid cells }\end{array}$ & Yes $^{\S}$ & {$[13,50]$} \\
\hline \multicolumn{4}{|c|}{$\begin{array}{l}\text { †Authors' translation of non-English text. } \\
\text { ¥Taiwan was viewed separately from China as a country, although it is traditionally referred to as an economy because of its relationship with/to China. } \\
\text { \&US law only applies to federal funding. Non-federal funded human embryo or embryoid research has no restrictions unless implanted into a uterus (at which point the US Food } \\
\text { and Drug Administration has oversight). } \\
\text { Sixteen countries define human embryos or other entities within national laws or guidelines. Of those countries, seven (Australia, Austria, Belgium, Germany, Japan, Russia and } \\
\text { the USA) restrict (or could be perceived as restricting) embryoid research. } \\
\text { NA: No applicable guideline or law. }\end{array}$} \\
\hline
\end{tabular}


does not involve fertilization, they are permissive in this regard [71-73,79,81-83]. Furthermore, in Spain, researchers are permitted to use alternative methods to create an embryo, including SCNT and parthenogenesis, and therefore embryoids developed from PSCs (hESC or iPSCs) are permissible.

Switzerland's Stem Cell Research Act defines an embryo as an "offspring, from the fusion of the cell nuclei (karyogamy) to the completion of organ development" [60]. Since embryoids are derived from PSCs and do not involve nuclei fusion or fertilization, these laws permit embryoid research [60]. Furthermore, the Swiss 7-day limit within the law specifically states that it only applies to embryos used for research or the development of hESC lines. It does not cover culturing hESCs into later stages of development. Therefore, it allows for embryoids, including ones mimicking stages after 7 days, such as gastruloids.

An additional three countries - Austria, Russia and Sweden - do not define embryos; however, their laws or guidelines contain similar terms or cover embryoid research. Sweden's law uses the term 'fertilized egg' instead of embryo, which therefore does not apply to embryoids and thus allows research on them [62]. Both Austria and Russia have no definition of an embryo, but their laws describe prohibitive activities that also ban embryoid research [52,59]. Austria's law references cells capable of development in its language banning human embryo research, which applies to embryoids as well. Russia's policy prohibiting hESC and human embryo research covers also embryoid research.

Six countries - Brazil, China, France, Israel, Italy, Turkey - do not contain a definition of an embryo or similar entities. All six nations are permissive of human embryoid research. Brazil's law and China's national guidelines apply to hESC research and do not explicitly cover human embryo research nor include embryoids [41,78]. France's law requires approval for hESC research, including hESC-derived embryoid research, by the Agency of Biomedical Research, but does not restrict embryoid research from iPSCs [47,48]. While Israel has no embryo definition, their guidelines permit human embryo research that will not be used for implantation - making their guidelines permissive for in vitro work on embryoids. Turkey and Italy only allow human embryos to be created for reproductive purposes, limiting their storage, and not allowing the option of donations for research. However, human embryoids, created from existing PSCs, are outside the scope of the laws and therefore permitted [56,58].

\section{Discussion \& conclusion}

This review of human embryo research-related legislation and guidelines is limited to only 22 countries. However, it highlights the similarities and differences between national contexts, focusing on major investors in R\&D that are also the major influences on R\&D policy [38,39]. The views of the human embryo and embryoids as a research tool vary internationally from permissive to completely prohibitive.

Our analysis found that a 14-day limit existed in the majority of national laws and guidelines but is not universally used [2]. Although the US is the largest R\&D funder in terms of total GERD (Table 1), it only has voluntary guidelines for human embryo research in place; there is no federal law [13,38]. However, scientists are obligated to follow funding restrictions, state laws and prevailing guidelines from scientific and medical societies, which research institutions have almost universally adopted. While scientists can do research on human embryos, and even work beyond 14 days, these restrictions and guidelines still represent significant barriers. However, this could also allow a rogue scientist to do questionable work with human embryos without regard for public opinion on the ethical and scientific validity of the research, similar to what has controversially occurred already with germ-line editing of a human embryo [87]. Furthermore, there has been no clear guidance to US scientists regarding the Dickey-Wicker Amendment's effect on federal funding for human embryoid research. This uncertainty could be alleviated by the adoption of national guidelines for both human embryo and embryoid research.

While many countries have national laws and/or guidelines focused on hESC and human embryo research, their position toward embryoid research has often not been addressed. To determine whether a restriction to embryoid research exists requires a careful review of the language and associated definitions within national laws and guidelines. Generally, if a country in our study permitted hESC research, then conducting embryoid research was legal. However, this was not always the case. For example, as discussed earlier, Australia allows hESC and human embryo research but restricts embryoid research [66-68]. In contrast, Italy and Turkey ban human embryo research and the derivation of hESC lines, but the laws only affect IVF donated eggs [56,58]. Therefore, embryoid research using existing hESC lines (created in another country) or iPSCs is allowed.

Several national laws and guidelines restrict embryoid research, whether intentionally or not. For instance, Dutch, Belgian, and Australian laws use potential or the ability of cells to become a human as a marker for whether or not research is acceptable [85,86]. However, the laws do not define what 'potential' means, if embryoids have the 
potential to be humans, or at what point they would gain that potential - concerns which might not have been seen as important when the laws were developed to address hESC research or reproductive cloning.

Many national laws and guidelines reviewed were developed to address other issues such as reproductive cloning, hESC research, and/or human embryo research, but now several are being applied to embryoids [64]. For example, Australia's embryo definitions in their hESC research and cloning laws have been interpreted to prohibit human embryoid research [66-68]. In the US, NIH officials are limiting some research on embryoids out of concern that it might violate the Dickey-Wicker Amendment [10,13,50]. Scientists must now interpret embryo definitions within national laws and/or guidelines to determine what is and is not permitted. To clarify what research is permissible and prohibited, embryoid research needs its own set of guidelines, separate from hESC and human embryo research policies, as concerns and potential solutions will be different $[1,85]$.

Embryoids can be used as an alternative to human embryo research and play a role in uncovering knowledge about early embryo development without the use and destruction of a human embryo. This makes embryoids less ethically challenging and a useful scientific tool. Yet, there still are concerns about embryoid research that need to be addressed. As research models progress, embryoids will become more sophisticated and more embryo-like [1,3,85,86]. It is unclear when they will achieve a level of intricacy in which they should be viewed as similar enough to an embryo - at least from a regulatory perspective. Arguments, dating back to the Warnock and DHEW reports remain unresolved related to when, how, or what factors signify that an embryo should receive full moral status as a person $[1,11,12,85]$.

Furthermore, embryoids do not fall within the 14-day limit. Embryoids do not progress linearly; instead they mimic specific developmental points. For example, an embryoid could mimic gastrulation (around day 17 in actual human embryos) in less than 14 days but without having developed the primitive streak $[3,10,85,86]$. Instead of a deadline model, embryoid regulation should focus on the entities themselves, such as which cells they contain (e.g., extra-embryonic tissue) or their ability to develop complex structures (such as neural connections) [85]. However, determining the exact limits will be a complicated endeavor in itself.

Overall, as scientists and scholars discuss the relevance of this 14-day limit as well as the expansion of human embryoid and human embryo research, they should also be aware of the national laws and guidelines that affect their work. Collaborating with policymakers and invested stakeholders could highlight unclear laws, amend confusing language, and develop laws and guidelines to promote research, as appropriate in each national context.

\section{Future perspective}

Human embryo and embryoid research will continue to expand along with ethical questions and discussions about the work. Regardless of whether there is a 14-day limit in place or it is replaced by another time point or regulation, human embryo research will be restricted based on resources available, both in terms of available cells (donated embryos, sperm and/or eggs) as well as funding, especially in the USA, where scientists must rely on limited state and private funds for research. With the emergence of China in the past decade as a major player in $R \& D$, new perspectives related to the ethics of human embryo research will arise, beyond the Judeo-Christian beliefs that dominated the USA and UK discussions on the subject in the past $[11,12]$. However, recent concerns related to heritable germline modification of human embryos could delay expansion for human embryo research beyond day 14 [87]. In contrast, human embryoid research faces less obstacles for expansion, especially if it is seen as an ethical alternative to human embryo research and allowed to continue without political restrictions. Instead, the focus will be on whether limits need to be created, how sophisticated the models should be, and/or how late in development they should go.

To encourage research in this area, scientists will need to engage with invested and interested stakeholders, such as funders, religious leaders (concerned about the use of embryos in research), donors, patients, and others who might gain from knowledge obtained from human embryo and embryoid research. For example, US scientists could model engagement after the work in the early 2000s where US hESC scientists engaged with stakeholders, especially patient advocates and private foundations, to push for more permissive hESC policies (which they obtained in 2009 at the beginning of the Obama Administration). Working with stakeholders to develop thoughtful and appropriate guidelines would acknowledge the sensitive nature of the work, provide an opportunity for public engagement, and promote high-quality science. Otherwise, scientists run the risk of losing public trust and seeing more restrictive regulations being instituted. 


\section{Executive summary}

- The 14-day limit is a boundary that prohibits researchers from culturing an in vitro human embryo beyond 14 days after fertilization or the development of the primitive streak.

- New technological developments allow scientists to culture human embryos in vitro beyond day 14.

- Scientists are using organized pluripotent stem cell models - embryoids - to study early human development.

- Reviewing national laws and guidelines from the top 22 major research and development (R\&D) investing countries allows for a fuller understanding of science policies in the countries who have the most impact.

Human embryo national laws \& guidelines

- Of the 22 top science and technology R\&D intensive countries, 12, including the UK, have a 14-day limit; one, Switzerland, has a 7-day limit and five prohibit human embryo research.

- The USA is one of four countries without a 14-day limit or other restriction on human embryo research.

Embryoid policies

- Thirteen countries have definitions of embryo in a national law or guideline: Australia, Belgium, Canada, Germany, India, Japan, the Netherlands, South Korea, Spain, Switzerland, Taiwan, UK and the USA.

- Human embryo definitions vary, as does their impact on embryoid research, with some (Canada) permitting research and others (Australia) prohibiting it.

- Three countries - Austria, Russia and Sweden - do not define an embryo; however, their laws or guidelines contain similar terms or cover embryoid research.

- Seven countries - Australia, Austria, Belgium, Germany, Japan, Russia, and the USA - have restrictions on embryoid research.

- The remaining 15 countries permit embryoid research, but none address embryoid research explicitly.

Conclusion

- The 14-day limit is the most common human embryo research restriction, but it is not universally accepted in all top $R \& D$ countries.

- Most national laws and guidelines are ambiguous about embryoid research, leaving it unclear what is and is not permitted.

- Several countries limit research on cells with the potential to become a human embryo; this affects researchers' ability to conduct embryoid research when potential is not defined.

- Embryoid research will need its own set of guidelines, separate from hESC and human embryo research policies, since it address a different set of ethical and scientific issues.

\section{Author contributions}

KRW Matthews designed the project, reviewed the policies and drafted the manuscript. D Moralí identified and translated national laws and guidelines, organized tables and edited the final manuscript.

\section{Acknowledgments}

The authors would like to acknowledge the project team: A Brivanlou, AS Iltis, I de Melo-Martin, JS Robert and DS Wagner. We would also to thank the Rice University staff and students who helped research and edit the manuscript, especially N Gallego Marquez.

Financial \& competing interests disclosure

Funding for this project was provided by The Greenwall Foundation 'Making a Difference' grant (http://dx.doi.org/10.13039/10 0001146) and the Baker Institute Center for Health and Biosciences. The authors have no other relevant affiliations or financial involvement with any organization or entity with a financial interest in or financial conflict with the subject matter or materials discussed in the manuscript apart from those disclosed.

No writing assistance was utilized in the production of this manuscript.

\section{Open access}

This article is distributed under the terms of the Creative Commons Attribution License 4.0 which permits any use, distribution, and reproduction in any medium, provided the original author(s) and the source are credited. To view a copy of the license, visit http://creativecommons.org/licenses/by/4.0/

\section{References}

Papers of special note have been highlighted as: $\bullet$ of interest; $\bullet \bullet$ of considerable interest

1. Rivron NC, Pera M, Rossant J et al. Debate ethics of embryo models of stem cells. Nature 564(7735), 183 (2018).

-. Commentary discussing why embryoid research is important and makes recommendations for policy. 
2. Hyun I, Wilkerson A, Johnston J. Embryo policy: revisit the 14-day rule. Nature 533(7602), 169-171 (2016).

3. Aach J, Lunshof J, Iyer E, Church GM. Addressing the ethical issues raised by synthetic human entities with embryo-like features. eLife 6, e20674 (2017)

4. Chan S. How and why to replace the 14-day rule. Curr. Stem. Cell Rep. 4(6), 228-234 (2018).

5. Hurlbut BJ, Hyun I, Levine A et al. Revisiting the Warnock rule. Nature Biotech. 35(12), 1029-1042 (2017).

- Provides a range of opinions on the 14-day rules by leading scientists, policy scholars and ethicists.

6. Appleby JB, Bredenoord AL. Should the 14-day rule for embryo research become the 28-day rule? EMBO Mol. Med. 10(9), e9437 (2018).

7. Cavaliere G. A 14-day limit for bioethics: the debate over human embryo research. BMC Med. Ethics 18(1), 38 (2017).

8. Pera MF. Human embryo research and the 14-day rule. Development 144(11), 1923-1925 (2017).

9. Williams K, Johnson MH. Adapting the 14-day rule for embryo research to encompass evolving technologies. Reprod. Biomed. Soc. Online 10, 1-9 (2020).

10. Hurlbut JB. Experiments in Democracy: Human Embryo Research and the Politics of Bioethics. Columbia University Press, NY, USA (2017).

-. An historical review and analysis of human embryo research guidelines. This book contains a wealth of information on policies, policy recommendations and how decisions were developed.

11. US Department of Health, Education, and Welfare (DHEW) Ethics Advisory Board. Report and Conclusions: HEW Support of Research Involving Human in vitro Fertilization and Embryo Transfer. US Government Office of Printing, Washington, DC, USA (1979).

12. Warnock M. Report of the Committee of Inquiry into Human Fertilisation and Embryology. Her Majesty's Stationery Office, London, UK (1984).

13. Matthews KRW, Rowland ML. Stem cell policy in the Obama Age: UK and US perspectives. Regen. Med. 6(1), 125-132 (2011).

- While a few years old, this paper is still accurate and gives and overview of USA and UK human embryonic stem cell and human embryo research policies.

14. ISSCR (International Society for Stem Cell Research). Guidelines for Stem Cell Research and Clinical Translation (2016). www.isscr.org/docs/default-source/all-isscr-guidelines/guidelines-2016/isscr-guidelines-for-stem-cell-research-and-clinical-translationd 67119731dff6ddbb37cff0000940c19.pdf?sfvrsn=4

15. Kimmelman J, Hyun I, Benvenisty N et al. Policy: global standards for stem-cell research. Nature 533(7603), 311-313 (2016).

16. Daley G, Hyun I, Apperley JF et al. Setting Global Standards for Stem Cell Research and Clinical Translation: The 2016 ISSCR Guidelines. Stem Cell Reports 6(6), 787-797 (2016).

17. US National Academies of Sciences, Engineering, and Medicine (NASEM). Final Report of the National Academies' Human Embryonic Stem Cell Research Advisory Committee and 2010 Amendments to the National Academies' Guidelines for Human Embryonic Stem Cell Research. The National Academies Press, Washington, DC, USA (2010).

18. Shahbazi MN, Jedrusik A, Vuoristo $S$ et al. Self-organization of the human embryo in the absence of maternal tissues. Nat. Cell Biol. 18(6), 700-708 (2016).

19. Deglincerti A, Croft GF, Pietila LN, Zernicka-Goetz M, Siggia ED, Brivanlou AH. Self-organization of the in vitro attached human embryo. Nature 533(7602), 251-254 (2016).

20. Rivron NC, Frias-Aldeguer J, Vrij EJ et al. Blastocyst-like structures generated solely from stem cells. Nature 557(7703), 106 (2018).

21. Van den Brink SC, Baillie-Johnson P, Balayo T et al. Symmetry breaking, germ layer specification and axial organisation in aggregates of mouse embryonic stem cells. Development 141(22), 4231-4242 (2014).

22. Warmflash A, Sorre B, Etoc F, Siggia ED, Brivanlou AH. A method to recapitulate early embryonic spatial patterning in human embryonic stem cells. Nat Methods 11(8), 847-854 (2014).

23. Simunovic M, Brivanlou AH. Embryoids, organoids and gastruloids: new approaches to understanding embryogenesis. Development 144(6), 976-985 (2017).

24. Shahbazi MN, Siggia ED, Zernicka-Goetz M. Self-organization of stem cells into embryos: a window on early mammalian development. Science 364(6444), 948-951 (2019).

-• Excellent review of embryoid research and lists the variations based on developmental point and cells used.

25. Rossant J, Tam PPL. Exploring early human embryo development. Science 360(6393), 1075-1076 (2018).

26. Wallingford JB. The 200-year effort to see the embryo. Science 365(6455), 758-759 (2019).

27. Heemskerk I, Warmflash A. Pluripotent stem cells as a model for embryonic patterning. Dev. Dyn. 245(10), 976-990 (2016).

28. Zheng Y, Xue X, Shao Y et al. Controlled modelling of human epiblast and amnion development using stem cells. Nature 573(7774), 421-425 (2019).

29. Shao $\mathrm{Y}$, Taniguchi K, Townshend R et al. A pluripotent stem cell-based model for post-implantation human amniotic sac development. Nature Commun. 8(1), 208 (2017). 
30. Wysocka J, Rossant J. 2018 ISSCR Strategic Planning: looking to the future. Stem Cell Reports 12(6), 1183-1185 (2019).

31. Laurent J, Blin G, Chatelain F et al. Convergence of microengineering and cellular self-organization towards functional tissue manufacturing. Nature Biomed. Eng. 1(12), 939-956 (2017).

32. Shahbazi MN, Zernicka-Goetz M. Deconstructing and reconstructing the mouse and human early embryo. Nat. Cell Bio. 20(8), 878-887 (2018).

33. Martin GR, Evans MJ. Differentiation of clonal lines of teratocarcinoma cells: formation of embryoid bodies in vitro. PNAS 72(4), 1441-1445 (1972).

34. Martin GR. Isolation of a pluripotent cell line from early mouse embryos cultured $\mathrm{n}$ medium conditioned by teratocarcinoma stem cells. PNAS 78(12), 7634-7638 (1981).

35. Evans MJ, Kaufman MH. Establishment in culture of pluripotent cells from mouse embryos. Nature 292(5819), 154-156 (1981).

36. Sozen B, Amadei G, Cox A et al. Self-assembly of embryonic and two extra-embryonic stem cell types into gastrulating embryo-like structures. Nat. Cell Biol. 20(8), 979-989 (2018).

37. Gottweis H, Prainsack B. Emotion in political discourse: contrasting approaches to stem cell governance in the USA, UK, Israel and Germany. Reg. Med. 1(6), 823-829 (2006).

38. National Science Board, National Science Foundation. Research and Development: US Trends and International Comparisons. In: Science and Engineering Indicators VA, USA (2020). 2020 NSB-2020-3. https://ncses.nsf.gov/pubs/nsb20203/

39. National Science Board, National Science Foundation. Publications Output: U.S. Trends and International Comparisons. In: Science and Engineering Indicators 2020 VA, USA (2020). NSB-2020-3. https://ncses.nsf.gov/pubs/nsb20206

40. Wagner CS. The Collaborative Era in Science: Governing the Network. Palgrave MacMillan, CH, USA (2018).

41. (Brazil) Biosafety Law (2005, amended 2007) 11.105 (in Portuguese) (2005). www.planalto.gov.br/ccivil_03/_Ato2004-2006/2005/Lei/L11105.htm

42. Palma V, Pitossi FJ, Rehen SK, Tourino C, Velansco I. Stem cell research in Latin America: update, challenges and opportunities in a priority research area. Regen. Med. 10(6), 785-798 (2015).

43. Pranke P, Cahastelles P, Sperling LE. The current state of research with human pluripotent stem cells in Brazil. Stem Cells Dev. 23(1), 20-23 (2014).

44. (Israel) Public Health Regulations (Extra-Corporeal Fertilization), KT (1987) 5035 p. 978 (1987). www.gov.il/he/Departments/Dynami cCollectors/gazette-official?skip=0\&limit $=10 \&$ BookletNum=5035\&FolderType=3\&PublishDate_to=1988-01-01

45. (Israel) Prohibition on Genetic Intervention (Human Cloning and Genetic Change in Reproductive Cells) Law, SH (1999, Amended 2016) 1697 , p. 47.

46. (Israel) Egg Donation Law SH (2010) 2242 p. 520 (2010). https://fs.knesset.gov.il/18/law/18_lsr_300729.pdf

47. (France) Code of Public Health. Research on Embryos and Embryonic Stem Cells, Articles L2151-1 to L2151-8. (2000, amended 2002, 2004, 2011, 2012, 2016) (2000). www.legifrance.gouv.fr/affichCode.do;jsessionid=A2CCF9A1C5604695D4F4255350F3C4EC.tplgf r38s_3?idSectionTA=LEGISCTA000006171138\&cidTexte=LEGITEXT000006072665\&dateTexte $=20200504$

48. Drabiak-Syed K. New President, New Human Embryonic Stem Cell Research Policy: Comparative International Perspectives and Embryonic Stem Cell Research Laws in France. Biotechnol. Law Rep. 32(6), 349-356 (2013).

49. Rouquette P. France's controversial bioethics bill reaches Senate amid continuing outcry. France 24 (2020). www.france24.com/en/20200120-france-s-controversial-bioethics-bill-reaches-senate-amid-continuing-outcry

50. (United States) Further Consolidated Appropriation Act. H.R. 1865, $116^{\text {th }}$ Cong. Sec. 508 [Dickey-Wicker Amendment] (2020). www.congress.gov/bill/116th-congress/house-bill/1865/text

51. Matthews KRW, Yang E. "Politics and Policies Guiding Human Embryo Research in the United States.” Baker Institute Report (2019). https://doi.org/10.25613/vbe8-z426

52. (Austria) Reproductive Medicine Act (1992, amended 2001, 2004, 2008, 2009, 2010, 2014, 2015, 2018) 275 (in German) (1992). www.ris.bka.gv.at/GeltendeFassung.wxe?Abfrage=Bundesnormen\&Gesetzesnummer=10003046

53. (Germany) Embryo Protection Act (1990, amended 2011) 2746 (in German) (1990). www.gesetze-im-internet.de/eschg/

54. (Germany) Stem Cell Act (2002, amended 2017) 2277 (in German) (2002). www.gesetze-im-internet.de/stzg/index.html

55. German Ethics Council. Stem cell research - new challenges for the ban on cloning and treatment of artificially created germ cells? Deutscher Ethikrat, Berlin, Germany (2014).

www.ethikrat.org/fileadmin/Publikationen/Ad-hoc-Empfehlungen/englisch/recommendation-stem-cell-research.pdf

56. (Turkey) Regulation on Assisted Reproductive Treatment Practices and Assisted Reproductive Treatment Centers (1987, Amended 2014) (1987). www.resmigazete.gov.tr/eskiler/2014/09/20140930-4.htm

57. Gurtin ZB. Banning reproductive travel: turkey's ART legislation and third-party assisted reproduction. Reprod. Biomed. Online 23(5), 555-564 (2011).

58. (Italy) Rules on medically assisted procreation (2004) 40 (in Italian) (2004). www.camera.it/parlam/leggi/04040l.htm 
59. (Russia) Federal Law On Biomedical Cell Products (2016) 180-FZ (2016). www.gratanet.com/up_files/biomedical_cell_products_russia_june2016_eng.pdf

60. (Switzerland) Federal Act on Research Involving Embryonic Stem Cells (Stem Cell Research Act, StRA) (2003, amended 2005, 2014) 810.31 (2003). www.admin.ch/opc/en/classified-compilation/20022165/index.html

61. UK Human Fertilisation and Embryology Act 1990 (1990, amended 2008) 37 (1990). www.legislation.gov.uk/ukpga/1990/37/contents

62. (Sweden) Law on Genetic Integrity (2006, amended 2009, 2010, 2013, 2014, 2016, 2017, 2018, 2019) 351 (in Swedish) (2006). www.riksdagen.se/sv/dokument-lagar/dokument/svensk-forfattningssamling/lag-2006351-om-genetisk-integritet-mm_sfs-2006-351

63. (Belgium) Act Regarding Research on Embryos In Vitro (2003) 2156 (in French) (2003). www.ejustice.just.fgov.be/eli/loi/2003/05/11/2003022592/moniteur

64. Gopalan N, Mohamed MS, Nor SNM. Global Human Embryonic Stem Cell Laws and Policies and Their Influence on Stem Cell Tourism. Biotechnol. Law Rep. 37(5), 255-269 (2018). https://doi.org/10.1089/blr.2018.29088.ng

65. Sleeboom-Faulkner M, Hwang S. Governance of stem cell research: public participation and decision-making in China, Japan, South Korea and Taiwan. Soc. Stud. Sci. 42(5), 684-708 (2012).

66. (Australia) Prohibition of Human Cloning for Reproduction and the Regulation of Human Embryo Research Amendment Act (2006) 172 (2006). www.legislation.gov.au/Details/C2006A00172

67. (Australia) Prohibition of Human Cloning for Reproduction Act (2002, amended 2017) 144 (2002). www.legislation.gov.au/Latest/C2017C00306

68. (Australia) Research Involving Human Embryos Act (2002, amended 2016) 145 (2002). www.legislation.gov.au/Latest/C2016C00968

69. (Canada) Assisted Human Reproduction Act, S.C. (2004, amended 2006, 2007, 2012, 2019, 2020) c. 2 (2006). http://laws-lois.justice.gc.ca/eng/acts/A-13.4/FullText.html

70. (Canada) Canadian Institutes of Health Research, Natural Sciences and Engineering Research Council of Canada, and Social Sciences and Humanities Research Council. "Tri-Council Policy Statement: Ethical Conduct for Research Involving Humans.”. Secretariat on Responsible Conduct of Research, ON, Canada (2018).

71. (Taiwan) Assisted Reproduction Act (2007, amended 2018). https://law.moj.gov.tw/ENG/LawClass/LawAll.aspx?pcode=L0070024

72. (Taiwan) Department of Health. "Policy Instructions on the Ethics of Human Embryo and Embryonic Stem Cell Research.". Department of Health, Taipei, Taiwan (2007).

73. (Taiwan) Human Embryo and Embryonic Stem Cell Act (2011). (in Chinese) www.google.com/url?client=internal-element-cse\&cx=012254495936870409035:lzvyrg0mtim\&q=https: //dep.mohw.gov.tw/DOMA/dl-16081-e0ebe665-e7bc-4ae1-be36-2c5e037b39ed.html\&sa=U\&ved=2ahUKEwi86PikorTpAhVPT6 wKHTy5BysQFjAEegQIBhAB\&usg=AOvVaw32f6BL4xsMddLM0osjEbWe

74. Bubela T, Kleiderman E, Master Z et al. Canada's Assisted Human Reproduction Act: Pragmatic Reforms in Support of Research. Front. Med. (Lausanne) 6, 157 (2019).

75. Ogbogu U, Zarzeczny A, Baltz J et al. Research on Human Embryos and Reproductive Materials: Revisiting Canadian Law and Policy. Healthc. Policy 13(3), 10-19 (2018).

76. (Japan) Act on Regulation of Human Cloning Techniques (2000) 146 (2000). www.cas.go.jp/jp/seisaku/hourei/data/htc.pdf

77. (Japan) Ministry of Education, Culture, Sports, Science and Technology. Guidelines on the Derivation and Distribution of Human Embryonic Stem Cells. Ministry of Education, Culture, Sports, Science and Technology, Tokyo, Japan (2009). www.lifescience.mext.go.jp/files/pdf/n743_00.pdf

78. (China) Ministry of Science and Technology and Ministry of Health. "Ethical guidelines for human embryonic stem cell research.”. (in Chinese) Ministry of Science and Technology and Ministry of Health, Beijing, China (2003). http://most.gov.cn/fggw/zfwj/zf wj2003/200512/t20051214_54948.htmhttp://www.cncbd.org.cn/News/Detail/3376

79. (India) Indian Council of Medical Research \& Department of Biotechnology. National Guidelines for Stem Cell Research. Indian Council of Medical Research, New Delhi, India (2017). www.dbtindia.gov.in/sites/default/files/National_Guidelines_StemCellResearch-2017.pdf

80. (Netherlands) Embryo Act (2002, revised 2007, 2008, 2011, 2013, 2018, 2019). (in Dutch) (2002). https://wetten.overheid.nl/jci1.3:c:BWBR0013797\&z=2019-04-02\&g=2019-04-02

81. (Spain) Biomedical Research Law (2007, amended 2011) 14 (in Spanish) (2017). www.boe.es/eli/es/1/2007/07/03/14

82. (Spain) Techniques of Assisted Human Reproduction Law (2006, amended 2007, 2011, 2015) 14 (in Spanish) (2006). www.boe.es/eli/es/1/2006/05/26/14

83. (South Korea) Bioethics and Safety Act (2005, amended 2007, 2008, 2012, 2014, 2016, 2017) 7413.

84. Schoenwolf GC, Bleyl SB, Brauer PR, Francis-West PH. Third Week: Becoming Trilaminar and Establishing Body Axes. In: Larsen's Human Embryology (5th Edition). Elsevier Churchill Livingston, PA, USA, 57-81 (2015).

85. Hyun I, Munsie M, Pera MF et al. 2020 Towards guidelines for research on human embryo models formed from stem cells. Stem Cell Reports 14(2), 160-174 (2020). 
- A recent article highlighting issues associated with embryoids and regulations that limit them in the USA, Australia and UK.

86. Pera MF, de Wert G, Dondorp W, Lovell-Badge R et al. What if stem cells turn into embryos in a dish? Nat. Methods 12(10), 917-919 (2015).

87. Matthews KRW, Iltis AS. Are we ready to genetically modify a human embryo? Or is it too late to ask? Account Res. 26(4), 265-270 (2019). 